\title{
Utilising Bio-resources: Rational Strategies for a Sustainable Bio-economy
}





\title{
Utilising Bio-resources: Rational Strategies for a Sustainable Bio-economy
}

\author{
Michael Narodoslawsky \\ Graz University of Technology, Institute of Process and Particle Engineering \\ European Sustainable Energy Innovation Alliance [eseia] \\ narodoslawsky@tugraz.at \\ www.eseia.eu
}

Keywords

bio-economy, bio-resource utilisation, strong sustainability

\begin{abstract}
Although it is still not warranted to speak about the end of the fossil age, we certainly witness a trend towards renewable sources for energy and material. Properties of bio-resources however differ vastly from fossil as well as other renewable resources. They are storable, mainly de-central in their provision, have usually weak logistic properties and face severe competition from various sectors, in particular from the vital food sector. A stronger reliance on bio-resources to support the European energy system as well as to provide raw materials for conversion to material products therefore raises technical, societal and environmental issues that have to be resolved if a bio-economy is to become a viable development pathway.
\end{abstract}




\section{Table of Contents}

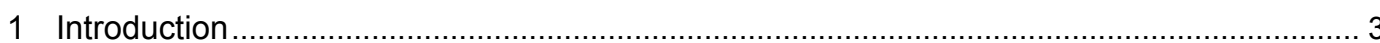

2 Bio-resources - versatile, contested and demanding base for human society ..................... 4

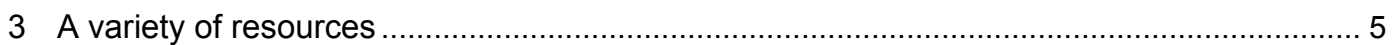

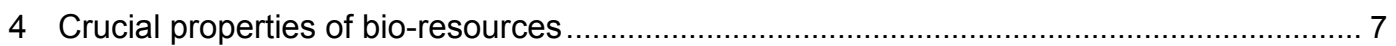

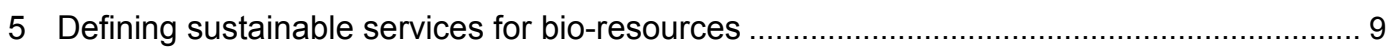

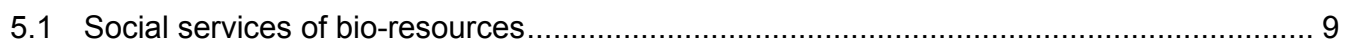

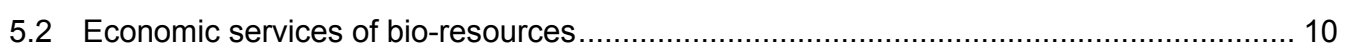

5.3 Environmental services of bio-resources................................................................. 12

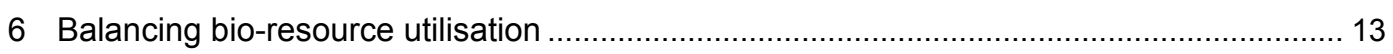

6.1 General rules resulting from the nature of bio-resources ......................................... 13

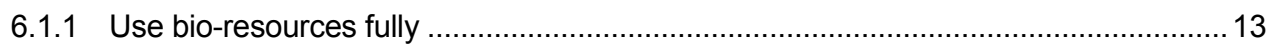

6.1.2 Life cycle wide responsibility for bio-resources .................................................... 14

6.2 Contextual rules for sustainably balancing bio-resource utilisation ................................. 14

6.2.1 Developing a sustainable bio-resource utilisation system..................................... 14

6.2.2 Heuristics for optimal regional bio-resource utilisation ............................................ 15

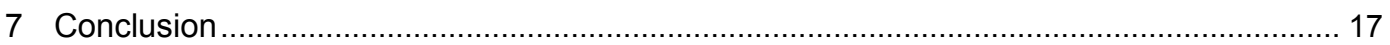

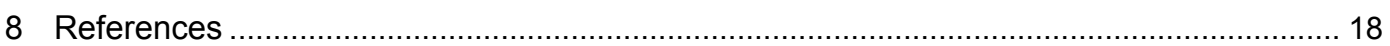

This paper refers to a talk given at the Institute of Technology Assessment (ITA) on April 29, 2014 and is based on the "discourse book" of the European Sustainable Energy Innovation Alliance on the rational utilisation of bio-resources. (See www.eseia.eu/wg1/. From this web page the "discourse book" resulting from this Europe wide expert discourse may be down-loaded. [accessed November 2014])

\section{MASTHEAD}

Media owner:

Austrian Academy of Sciences (ÖAW)

Legal person under public law (BGBI 569/1921 idF BGBI I 130/2003)

Dr. Ignaz Seipel-Platz 2, A-1010 Vienna

Editor:

Institute of Technology Assessment (ITA)

Strohgasse 45/5, A-1030 Vienna

www.oeaw.ac.at/ita

ITA manu:scripts appear at irregular intervals and publish working papers and talks from staff members as well as guests. ITA manu:scripts are exclusively made available to the public via the Internet portal „epub.oeaw”:

http://epub.oeaw.ac.at/ita/ita-manuscript

ITA-manu:script No.: ITA-14-02 (November/2014)

ISSN-online: 1818-6556

http://epub.oeaw.ac.at/ita/ita-manuscript/ita_14_02.pdf

(C) 2014 ITA - All rights reserved 


\section{Introduction}

The current discourse about ecological sustainability is heavily influenced by the concurrent discussions about the ecological threat global warming and the economic impact of diminishing fossil resources (Favennec, 2001). As a consequence an energy turn-around towards renewable resource based energy provision (as well as increased energy efficiency) is seen as a win-win-win option, at once relieving the burden on limited fossil resources, working against climate change and bringing society closer to sustainability. Besides this there are numerous voices such as Daniel Yergin (2011) linking development and implementation of renewable energies to technological innovation and economic growth, adding to the sustainability credentials of an energy turn-around. This has led to the formulation of political goals (e.g. the European Union 20-20-20 Goals, EC, 2007a) and plans (e.g. the European Union SET Plan, EC, $2007 \mathrm{~b}$ ) to lay the foundation for a change to renewable energies within the $21^{\text {st }}$ century.

Most of these plans call for equally dramatic increases in energy efficiency on the energy consumer side and in capacity of renewable energy technologies on the provision side of the energy system. The European Union Energy Roadmap 2050 as an example requires an energy demand drop between 32 and $41 \%$ and an increase of the share of renewable resource based energy provision by at least $55 \%$ in 2050 compared to 2005 . Although this increase in renewable energy provision will be shouldered by technologies drawing on different renewable resources such as hydro power, wind, direct solar energy, geothermal energy, wave and tidal energy, bioenergy will play an important role in the future energy mix.

This increased demand however meets an already contested resource. By 2050 the world population will increase to more than 9 billion people (from its current 7,2 billion), requiring over $10^{16} \mathrm{kcal}$ of food per year, an increase of over $40 \%$ from a current value of $7 * 10^{15} \mathrm{kcal} / \mathrm{y}^{1}$. Besides, well entrenched industrial sectors, most notable pulp and paper production and construction, already use large amounts of biomass. According to the $\mathrm{FAO}^{2}$ the world consumption for industrial round wood will reach $2.436 * 10^{9} \mathrm{~m}^{3} / \mathrm{y}$ wood raw material equivalent (WRME), $45 \%$ up from the 2005 consumption of $1.682 * 10^{9} \mathrm{~m}^{3} / \mathrm{y}$ WRME.

This means that bio-resource utilisation will require a delicate balancing act. This paper will discuss some issues that have to be taken into account if bio-resource utilisation is to be aligned with the requirements of sustainable development.

1 See e.g. (http://www.tasteofsustainability.com), based on FAO data http://faostat.fao.org/site/609/DesktopDefault.aspx?PagelD=609\#ancor [accessed June 2014]

2 See ftp://ftp.fao.org/docrep/fao/011/i0350e/i0350e02a.pdf for more information [accessed June 2014] 


\section{Bio-resources - versatile, contested and demanding base for human society}

There seems to be no other group of resources that can fulfil such a wide variety of demands as bio-resources. There is however no other group of resources that entail so direct and large scale impact on society and the environment for its provision and that so clearly highlight the general conundrum of sustainable development, namely living within "limited infinity". Bio-resources require as a basic production factor area, which is limited as our planet has a limited surface. Besides that it requires other ingredients, namely fertile environmental compartments, be they soil or water bodies.

Seen from the vantage point of converting solar energy into energy embodied in materials, the generation of bio-resources by the process of photosynthesis is not a particularly efficient process. Maximum theoretical conversion rates of solar radiation into bio-resources are between 4.6 for C-3 plants and 6\% for C-4 plants (Zhu et al., 2008). Practical conversion rates are around $50 \%$ of these theoretical values. Further conversion rates of plants to meat are between 5 to $50 \%$ (see e.g. FAO, 2006), making meat a particularly costly good when related to the natural solar income.

It is this low efficiency of converting solar radiation into useful energy from bio-resources (regardless if used for nutrition or technical purposes) that makes "living in limited infinity" particularly obvious: bio-resource generation rate is limited by the limitation of the production factors, most notably arable land and forest area. This rate may however be sustained over (practically) infinite time if human society learns to manage these production factors cleverly.

Human society is already a strong contender for this limited form of natural income. Beer et al. (2007) estimate Global Net Primary Production (NPP, the rate at which sunlight is converted into useful chemical energy, measured in $t$ of carbon fixed by photosynthesis per year) to roughly $105 \mathrm{Gt} / \mathrm{y}$, of which $53.8 \%$ are allotted to terrestrial systems. Haberl et al. (2007) show that from the terrestrial NPP $23.8 \%$ are already appropriated by men, be it by harvesting ( $53 \%$ of this appropriation) or land use change (amounting to $40 \%$ of the appropriation) or human-induced fires. They also point out that the overall impact of human activities reduces the NPP by almost $10 \%$. According to these authors it is far from certain that the current rate of appropriation is sustainable.

Limited generation rates are one aspect that makes bio-resources inherently contested commodities. Their versatility is another. From the vantage point of the energy sector and the chemical industry as well, bio-resources can fulfil every demand currently covered by various fossil (and nuclear) technologies: they may be converted in heat or electricity, fuel or any chemical compound demanded by the market. In a time when fossil oil, the key resource for synthetic materials and transport fuels faces its production maximum and, together with all other fossil resources, comes under increasing environmental scrutiny as a culprit of global climate change, the versatility of bio-resources translates into increased demand from various sectors. This adds to the already strong competition for bio-resources between traditional users, in particular the food sector, firewood use and pulp and paper industry, to name the most important ones.

Land as a basic production factor for most bio-resources is strictly limited on our planet. This means that any competition for bio-resources will inherently end up as a competition for land. On top of that different actors vying for most bio-resources have different preferences regarding the form of resource the use: the food sector needs crops of various kinds, pulp \& paper as well as construction industry need wood from forests whereas the chemical sector has the 
broadest portfolio of resources. This leads to direct competition between sectors, such as the competition for crops between the food sector and bio-fuel industry, but also to a competition between different forms of land use. Forests providing resources for energy provision or pulp \&paper industry may compete with fields that provide crops for food or bio-fuel.

Bio-resources are not only limited and seriously contested goods; they also demand other critical resources for their generation. Besides having a strong impact on local and regional water cycles agriculture is also the single most important consumer of fresh water. From the 3,862 $\mathrm{km}^{3} / \mathrm{y}$ of water removed in $2003^{3} 2,710 \mathrm{~km}^{3} / \mathrm{y}$ (or $70 \%$ ) where used by agriculture. The provision of crops in particular also requires large amounts of fertilizers (and causes environmental problems as a part of them are lost to ground and run-off water). The FAO (2008) reported a demand of $127,820,000 \mathrm{t} / \mathrm{y}$ of nitrogen as fertilizer in 2008 and estimates for 2012 are even $8.5 \%$ higher. This does not only add considerably to eutrophication of water bodies, it also requires large amounts of energy as even in state-of-the-art production plants $1 \mathrm{t}$ of nitrogen for fertilization requires about $40 \mathrm{GJ}$ of energy, provided usually via natural gas.

\section{A variety of resources}

One of the major differences to other (in particular fossil) resources is the wide variety of bioresources. This does not only concern the wide variety of plants and animals that man has domesticated for his purposes. It also applies to by-products and wastes from industrial and societal processes using primary bio-resources.

The intense competition for bio-resources (and hence for fertile land) applies in particular to the relative small number of primary agricultural crops and wood from forestry, leaving the oceanic fish resources mainly used for food out of consideration for a moment.

There is however another kind of bio-resources that is outside the current pattern of competition: secondary bio-resources that are by-products or wastes from agricultural, industrial or societal processes. Their use does in general not add to the direct competition for land although it may influence the fertility of land. In general their use is either in the form of a cascade (prolonging the value chain of a primary resource within society) or parallel to a valuable crop (using parts of plants that are usually not entering the markets such as straw and corn cobs) or additional (using land that is underutilised or otherwise not cultivated).

Table 1 shows some of these secondary bio-resources. As a rule of the thumb their overall global flow is in the order of magnitude of the current flow of agricultural products. These bioresources therefore offer a significant chance to alleviate the future resource burden.

Competition for, availability of and restriction for the use of these resources again vary widely. For some of them (e.g. tallow, straw, waste paper etc.) there exists already a certain market. For these resources it will be crucial if any innovative utilisation form (e.g. ethanol from straw) will lead to higher value for the resource and if their current service may be provided by other means at lower economic, environmental and social costs.

3 According to the web-page of the FAO Aquastat, an excellent source for data on water use: http://www.fao.org/nr/water/aquastat/dbase/AquastatWorldDataEng_20101129.pdf [accessed June 2014] 
Agricultural residues that are currently left on the fields serve in many cases as fertilisers. A full recovery of those residues may therefore endanger the sustainability of land use and thus undercut the objective to achieve a long term, environmentally benign resource provision. It requires careful management of soil quality by establishing maximum allowable withdrawal rates and possibly by returning nutrients from other sources to the land, namely wastes at the end of utilisation cascades such as ashes and manure. They must however conform to quality standards that allow their safe re-integration while at the same time returning substances that are valuable for maintenance of land productivity.

Table 1: Examples for secondary bio-resources (adapted from Gwehenberger \& Narodoslawsky, 2008)

\begin{tabular}{ll}
\hline Raw material category & Example \\
\hline Agricultural wastes & Manure \\
\hline Residues from industries & Slaughterhouse residues \\
& Glycerol from bio-diesel prod. \\
& Black liquor from pulping \\
& Sugar beet chips \\
\hline Residues from society & Waste paper \\
& Organic municipal waste \\
& Used vegetable oil \\
\hline Residues from energy provision & Waste water \\
\hline Harvest residues from agriculture/forestry & CO 2 \\
& Ashes \\
\hline Underutilised bio-resources & Low quality forest residues \\
\hline Products from currently not cultivated land & Straw from corn, cereals, oil seeds, ... \\
\hline
\end{tabular}

A challenge that is common to all the secondary bio-resources described here (and also to a large part of primary bio-resources) is the design and operation of an optimal logistical system for collecting the resources, distributing the products and possibly re-integrating waste flows into the environment. This will be discussed in more detail in the next chapter. 


\section{Crucial properties of bio-resources}

The most obvious dissimilarities between bio-resources and fossil resources are their different logistical parameters. If bio-resources have to play a more prominent role in energy provision and industry this means a radically changed economic and logistical structure of resource provision. Table 2 shows a comparison of humidity, transport density and energy content for some example resources.

Table 2: Comparison of logistic parameters for fossil and bio-resources (adapted from Gwehenberger \& Narodoslawsky, 2008)

\begin{tabular}{|c|c|c|c|c|c|}
\hline Conversion & Material & $\begin{array}{c}\text { Humidity } \\
{[\% w / w]}\end{array}$ & $\begin{array}{l}\text { Energy content } \\
\qquad[\mathrm{MJ} / \mathrm{kg}]^{1}\end{array}$ & $\begin{array}{l}\text { Density } \\
{\left[\mathrm{kg} / \mathrm{m}^{3}\right]^{1}}\end{array}$ & $\begin{array}{l}\text { Energy ensity } \\
\qquad\left[\mathrm{MJ} / \mathrm{m}^{3}\right]^{1}\end{array}$ \\
\hline \multirow[t]{6}{*}{ Incineration } & Straw [grey] & 15 & 15 & $100-135$ & 1.500-2.025 \\
\hline & Wheat [grains] & 15 & 15 & $670-750$ & $10.050-11.250$ \\
\hline & Rape seed & 9 & 24.6 & 700 & 17.220 \\
\hline & Wood chips & 40 & 10.4 & 235 & 2.440 \\
\hline & Split logs [beech] & 20 & 14.7 & $400-450$ & $5.880-6.615$ \\
\hline & Wood pellets & 6 & 14.4 & 660 & 9.500 \\
\hline \multirow{6}{*}{$\begin{array}{l}\text { Biogas } \\
\text { production }\end{array}$} & Grass silage & $60-70$ & 3.7 & $600-700$ & 2.220-2.590 \\
\hline & Corn silage & $65-72$ & 4.2 & 770 & 3.230 \\
\hline & Organic municipal waste & 70 & 2.4 & 750 & 1.800 \\
\hline & Manure & 95 & 0.7 & 1000 & 700 \\
\hline & Light fuel oil & 0 & 42.7 & 840 & 36.000 \\
\hline & Anthracite & 0 & 35,3 & $800-930$ & $28.000-33.000$ \\
\hline
\end{tabular}

${ }^{1}$ All numbers related to fresh material

The table lists two kinds of bio-resources, relatively dry material for which the energy content is calculated as the calorific value generated by incineration. For wet materials the energy content is defined by the energy content of biogas if these materials are subjected to an anaerobic fermentation.

Table 2 shows that bio-resources are characterised by high humidity and/or low transport density and generally lower energy content. In many practical cases therefore transport volume will become limiting for the collection logistic of these resources. The differences between fossil resources (represented here by light heating oil) and bio-resources are poignant: there is a factor of 24 between the energy density of straw and light heating oil with regard to their energy density 4 .

The logistical challenge becomes even more visible if different means of transportations are factored in. According to their energy efficiency (and strongly influenced by their particular ratio of empty weight to load capacity) transport systems require different energy to transport a load a certain distance. If we set the limit of the energy used to transport a resource to its utilisation site arbitrarily to $1 \%$ of the contained energy, we obtain the following results:

4 The disadvantage of wet resources must be put in perspective: biogas has a much broader range of applications than heat generated by incineration. 
- In case of manure, straw and corn silage $1 \%$ of the contained energy will power a tractor (as the most common short distance means of transportation on farms) $5.7,12$ or $18 \mathrm{~km}$ respectively;

- $1 \%$ of the energy contained in wood chips and split logs will power a truck for 40 and $100 \mathrm{~km}$ respectively;

- For wood pellets and corn a train will go for 475 and $525 \mathrm{~km}$ respectively using $1 \%$ of the transported energy content;

- An ocean going ship loaded with crude oil however will travel $7.800 \mathrm{~km}$ with $1 \%$ of the energy contained in its cargo.

These numbers highlight the spatial context of resource use: whereas it is fully rational to establish a global fossil economy as transport from source to utilisation plays almost no role, the use of bio-resources must become regional and possibly even local. This is particularly true for secondary bio-resources as they are characterised by especially disadvantageous logistic parameters.

There are many implications resulting from these crucial logistic properties of bio-resources that will be dealt with in the following chapters. One particularly interesting aspect concerns the technological approach to deal with large volumes of resources. In a fossil based economy the solution to more resources to be utilised is bigger plants: as bigger plants are more efficient and less costly than smaller plants (following the "economy of scale"), building bigger saves money and usually ecological impact.

This option is less attractive for bio-resources as bigger plant capacities also mean longer transport distances for collecting resources and re-integrating wastes. While economy of scale can still be an option for primary bio-resources, it certainly becomes problematic for utilising secondary bio-resources either as sole feedstock or for provision of energy. Gwehenberger et al. (2008) argue that de-central bio-ethanol plants powered by harvest residues show dramatically decreased ecological pressures compared to large scale conventional plants but that this advantage decreases when plant capacities exceed a certain size. In this case economy of scale runs contrary to ecology of scale. Rather than building larger plants the approach for secondary bio-resources may well be to design smaller components for serial production (thus reducing investment costs) and combine them into technology systems (bio-refineries, see below) optimally adapted to the spatial context. 


\section{Defining sustainable services for bio-resources}

Any attempt to balance the utilisation of bio-resources sustainably must be based on an analysis of the services that bio-resources have to fulfil for global sustainable development. This requires defining the social, economic and environmental services that bio-resources may provide and to analyse which of them can or cannot be performed by other resources or what the restrictions on other resources are to provide them in a sustainable way. When the services are defined we will look into means to provide these services by bio-resources sustainably and then deduce criteria guiding their utilisation in practice.

\subsection{Social services of bio-resources}

There is no doubt that the main societal service of bio-resources is to provide food for the global population. Bio-resources currently have a monopoly on this service although there have been numerous research attempts to generate food from fossil hydrocarbons (e.g. Gosh \& Banerjee, 1984) via biotechnological pathways. Providing food from limited fossil resources which are themselves highly contested however is no sustainable alternative.

It was already discussed in the introduction that human nutrition is no fixed consumer of bioresources. The actual utilisation of bio-resources for nutrition is strongly dependent on diet and life style parameters. As wealth in large countries like China and India as well as in Africa increases, the diet of the global population is shifting to a larger fraction of meat. Coupled with the still on-going global population growth it can lead to a considerable increase in the demand for meat and as a consequence more land dedicated to produce feed. Some estimates ${ }^{5}$ put the increase in per capita meat consumption from 2005 to 2050 at almost $68 \%$ (from 41 to 68,8 $\mathrm{kg} / \mathrm{cap} . \mathrm{a}$ ) and the total global meat consumption increase over the same period at $135 \%$ (from $266 \mathrm{Mt} / \mathrm{a}$ to $624 \mathrm{Mt} / \mathrm{a}$ ). Together with the already mentioned low efficiency of transforming solar energy into meat nutritional value this would mean a strong pressure on bio-resources.

Besides an increased meat consumption waste along the food provision chain is another factor associated with this societal service of bio-resources. A study commissioned by the FAO (Gustavsson et al., 2011) estimates that roughly one third (or $1.3 \mathrm{Gt} / \mathrm{a}$ ) of agriculturally produced food will perish or be wasted on farms, along the logistical chain or during consumption.

Bio-resources can only be utilised sustainably when they also provide the service of a sufficient base for the livelihood in rural regions. With the exception of regions featuring noteworthy mineral (or fossil) deposits, bio-resources are the only stable and sustainable base for rural regions with tourism in some cases supplementing to their economic viability.

5 T. E. Elam calculates in his treatise Projections of Global Meat Production Through 2050 meat consumption based on global GDP and population growth. Accessible via:

http://www.farmecon.com/Documents/Projections\%20of\%20Global\%20Meat\%20Production\%20Through\% 202050.pdf [accessed November 2014] 


\subsection{Economic services of bio-resources}

Wind power, solar thermal energy and photovoltaic will become major suppliers of electricity and electricity will become more prominent in any sustainable energy system (see e.g. The European SET Plan Roadmap, EU, 2007b). All these technologies convert solar energy much more efficiently into electricity than technologies based on bio-resources can do. The resources for these technologies are free of any cost for generation, giving them a key economic advantage over bio-resources (as well as over fossil and other resources). This economic advantage already becomes a change factor for the electricity system in Europe: the more wind power and PV enter the electricity market, the less room there is for conventional base load technologies like nuclear and large fossil based power plants.

All these renewable sources however are either periodically or intermittently available. This requires other approaches that stabilise the distribution grids, in particular for electricity. Besides management of power demand (by smart grids) the use of energy storage or material energy carriers (both fossil and bio-based) that pick up the gap between intermittent electricity provision will become necessary. The challenge then is however not anymore the provision of a large amount of base load electricity but to power technologies that are nimble enough to stabilise the distribution grids, that operate only when "cheap and green" wind or PV power is in short supply.

Following this argument, the cost of energy and in particular electricity storage will become crucial for a future energy system. Analysing the cost of electricity storage as in Figure 1 shows that bio-resources are an economically viable sustainable, non-fossil way to stabilise electricity grids. They become particularly interesting when factoring in that capacity for compressed air energy storage as well as for pumped storage plants are limited and in many cases geographically distant from the generation of cheap renewable wind power, necessitating large investment in grid infrastructure. A service provided by bio-resources in a sustainable economy therefore is to contribute considerably to the task of stabilising energy distribution grids, especially for electricity.

In the same line runs the argument for transport fuel. Currently this service is overwhelmingly provided by fossil oil, with the global share of bio-fuels currently at about $3 \%{ }^{6}$. Fuel for transport is inherently a storage issue. In addition to the arguments given above, considerations of energy density, weight of the storage system and range have to be taken into account. As more and more people concentrate in cities (the WHO expects $70 \%$ of the world population living in cities by $2050^{7}$ ) the overall pattern of transport may change considerably, with public transport, bicycles and electric vehicles providing mobility in urban regions. Dispersed settlements like in rural areas, long distance individual mobility, air traffic as well as ships will however require stored energy with high energy density, quick charge and low emissions. There is no doubt that fossil fuel (oil as well as natural gas) will still provide a major share of this service for many decades to come. Besides that, synthetic fuel (hydrogen from electrolysis with surplus electricity as well as $\mathrm{CO}_{2}$ converted to methane with this hydrogen) will possibly provide a share, too. Bio-fuels, as seen from Figure 1, may become a viable alternative for this service.

6 Data from IEA, accessible from http://www.iea.org/topics/biofuels/, [accessed July 2013]

7 Accessible from http://www.who.int/gho/urban_health/situation_trends/urban_population_growth_text/en/, [accessed November 2014] 


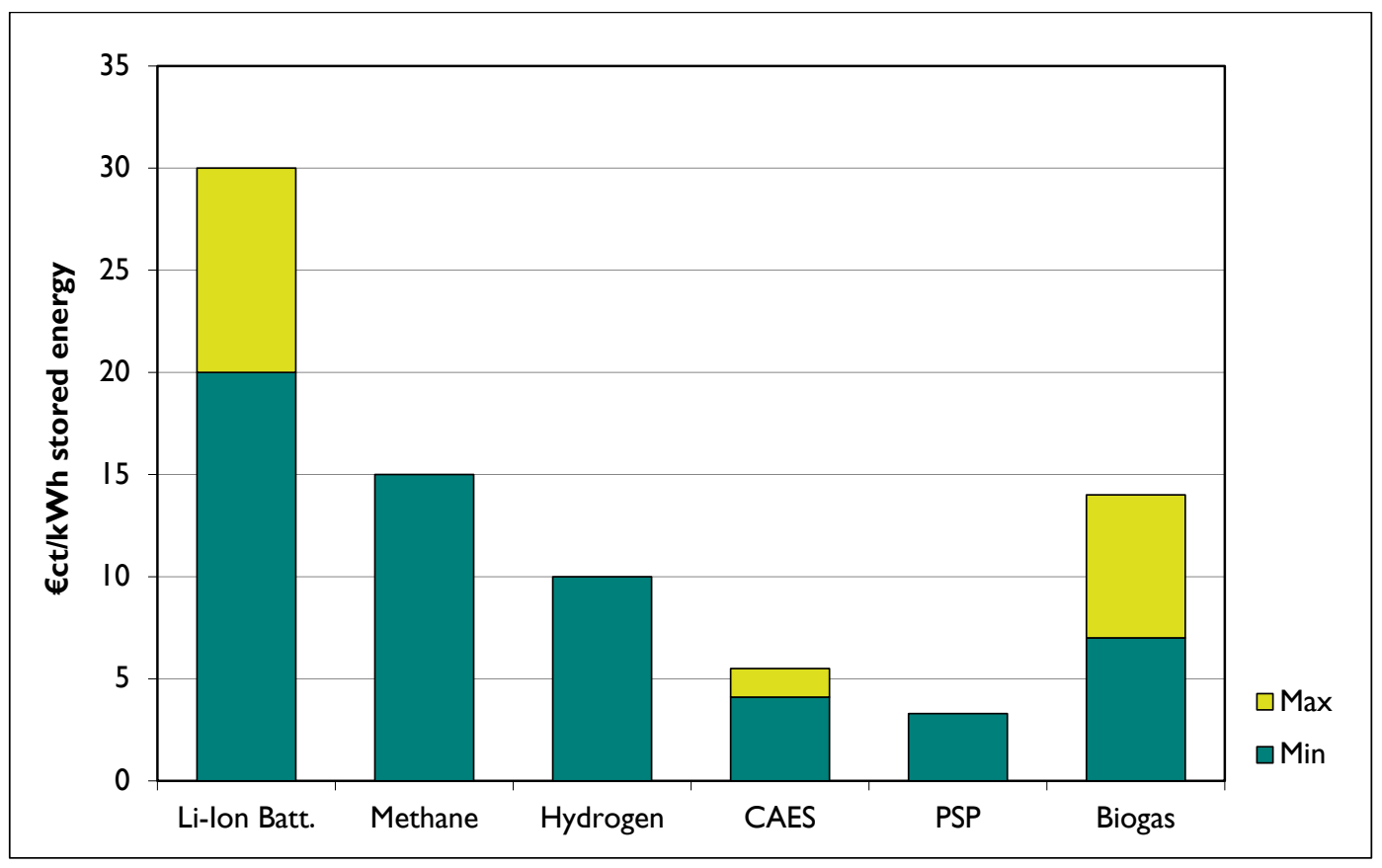

Figure 1: Cost of energy storage with data from Deutsche Bank (2012)

Li-Ion Batt. ...... Lithium-ion Battery
Methane ......... refers to methane generated by power-to-gas processes
Hydrogene ...... produced by electrolysis
CAES ............. Compressed Air Energy Storage
PSP............... Pump Storage of Power
Biogas........... produced from grass silage

Still another service relevant for economic sustainability is the provision of heat. Low temperature residential heat can be provided sustainably by solar thermal units, ground heat pumps (using electricity for their operation) and off-heat from thermal electricity provision or industry (distributed via district heating grids in urban areas). Low temperature heat may also be stored cheaply, with costs as low as $0.1 € \mathrm{ct} / \mathrm{kWh}$ (IEA-ETSAP \& IRENA, 2013).

The situation is however different for high temperature industrial heat. This service is currently covered by coal and natural gas, together with electricity for special applications (e.g. steel smelters). Alternatives on the base of renewable resources are however scarce. Although concentrated solar energy can reach high temperatures, this technology has considerable drawbacks. On the one hand it is only viable in places with high solar radiation and it shares periodic operation with all other direct solar technologies. On the other hand the large areas required directly at the site of energy production make this technology unwieldy for industrial applications. This opens the way for processed bio-resources like cleaned biogas and char coal that will have to contribute to the provision of high temperature industrial heat.

Bio-resources are a natural renewable source for organic chemicals and may therefore be used for generating plastic and other high-tech synthetic material. Today the global production of plastic reaches around $280 \mathrm{Mt} / \mathrm{y}^{8}$ and thus is an order of magnitude lower than the current human utilisation of wood. Current synthetic materials industry is supplied with fossil resources. The

8 Data from Plastics Europe, accessible from

http://www.plasticseurope.org/information-centre/press-room-1351/press-releases-2012/first-estimatessuggest-around-4-increase-in-plastics-global-production-from-2010.aspx, [accessed November 2014] 
magnitude of the global synthetic material production is in the order of the annual flow from the global carbon cycle to long term storage (via sedimentation to the ocean beds) and an order of magnitude lower than the consumption of fossil resources for energy purposes. The use of these materials will however increase with the quest for lighter and tougher materials of construction that allow the production of energy efficient goods. While the resource consumption for synthetic materials is certainly less of a problem than our fossil based energy system, considerable environmental problems are linked to the disposal of synthetic organic material.

Plastic production is directly linked to fossil oil refining, with oil refinery by-products providing the overwhelming part of the feedstock to polymerisation plants. Major increases in plastic production will have to cut into other utilisation pathways for crude oil if its production stagnates or even declines. The only alternative (besides recycling) is to use bio-resources to pick up the increasing gap between synthetic materials demand and crude oil refining by-products supply. This is a further service that can only be provided by bio-resources in a sustainable way.

It goes without saying that bio-resources will keep and possibly increase their role as feedstock for those industries that already now are based on these raw materials. The most prominent sectors here are pulp \& paper, and construction as well as smaller volume industries (in terms of resource utilisation) such as pharmaceuticals, cosmetics and wellness products, speciality lubricants and many others.

\subsection{Environmental services of bio-resources}

When discussing environmental services of bio-resources the main argument is almost always their contribution to greenhouse gas emission reduction. It is obvious that bio-resource based services in general have clear advantages on the count of greenhouse gas emissions compared with fossil based services and in particular that bio-energy has a much lower ecological footprint than either fossil or nuclear energy provision technologies (Kettl et al., 2011). Following the argument given above, bio-resources are, however, no general solution for a sustainable energy system. Kettl et al. (2011) show that bio-energy systems trail other renewable energy forms (e.g. wind and hydro power) in ecological performance. This means that also from an ecological point of view the application of bio-resources should be restricted to the services that cannot be provided economically and ecologically sensibly by other renewable sources, e.g. stabilising energy distribution grids and providing transport fuel and high temperature industrial heat. Their environmental service regarding greenhouse gas emission is to contribute crucial elements to a sustainable energy system, thus supporting a deep restructuring from fossil and nuclear based energy provision to a renewable resource based system.

The provision of bio-resources is arguably the broadest and most widespread human impact on the ecosphere. It changes landscapes as well as the quality of soils and water bodies, disturbs natural habitats and water cycles. Current agricultural practice entails massive flows of nitrogen, phosphor and mineral nutrients from industry and mineral deposits through fields to environmental compartments.

On top of that agriculture and forestry are responsible for managing fertile land and thus the very livelihood for man as well as all other creatures. The most important ecological service of bio-resources is therefore to maintain or even improve by their generation the long term productivity of fertile land and guarantee the co-evolution of all non-human natural partners. This requires careful management of soil quality and nutrients as well as considering water cycles and providing sufficient habitat to maintain bio-diversity. 


\section{Balancing bio-resource utilisation}

Balancing the use of bio-resources requires on the one hand adapting to the nature of these resources and on the other hand providing the services which bio-resources may offer in an optimal and sustainable way. Whereas the former requirement will result in general rules for the use of bio-resources, the latter can only be met on a concrete, context specific level. The following arguments will provide a rough framework for the balance of bio-resource utilisation from a sustainability point of view.

\subsection{General rules resulting from the nature of bio-resources}

There is one particular aspect of the nature of bio-resources that has to be taken into account when utilising these resources: their "limited infinity" nature, meaning that they are limited in terms of their flow (e.g. their yield per hectare and year), but this flow will be infinitely available if the basic ecological resource, in particular land, is managed sustainably. This gives raise to the following general rules.

\subsubsection{Use bio-resources fully}

As a limited but crucial basis for human survival and development bio-resource utilisation requires the highest possible efficiency of conversion into services. Wasted bio-resources mean that limited natural income has been squandered.

There are two aspects to this rule. The first is linked to the limiting factor of land as a production factor for bio-resources. Natural income is only then fully utilised if everything that land can sustainably produce is really also taken in by society. It is waste of natural income if what is left on the land after harvesting and is not required to maintain the productive quality of the land or does not serve any other service for the environment (e.g. supporting local closing of the water cycle, improvement of fertility or bio-diversity) or society (e.g. recreational services or improvement of cultural landscape) is not utilised.

This aspect is one reason why the concept of bio-refineries becomes so important for sustainable bio-resource utilisation. Off-spec parts of crops and low quality harvest residues will not be taken up in the food value chain but still constitute a considerable part of sustainable natural income in form of utilisable bio-resources. Integrated technology systems like bio-refineries are able to process these resources and provide energy services or commodity products.

The other aspect of this rule concerns the efficiency of the value chain based on bio-resources. Wasting crops, by-products or intermediate products along the life cycle of bio-resources from generation to end use or, even worse, wasting the end product itself clearly violates rational use of a strictly limited resource. It is this aspect that calls our current food logistic and consumption pattern in the developed countries in particular into question. The current waste of almost one third of agricultural products on the way to the consumer and subsequent waste of food by consumers leaves considerable lee-way to provide other bio-resource services with the same land use. 


\subsubsection{Life cycle wide responsibility for bio-resources}

This paper has argued consistently that bio-resources convert the natural income of solar radiation to a highly structured basic source of human development. This conversion however needs other production factors, the most prominent among them fertile land on which this conversion takes place. In addition the conversion requires water, $\mathrm{CO}_{2}$ and nutrients. Retaining the fertility of the land means that human utilisation of bio-resources has to latch into global material cycles for water, carbon and nitrogen and replace those nutrients that do not form natural cycles (such as minerals).

The moment a bio-resource is harvested responsibility for this material is transferred to human society. This means that any use of bio-resources requires careful management of the material life cycle starting with the harvest and ending with the re-integration of all residues after human use. Rational utilisation of bio-resources therefore requires the subordination of current waste management to the necessities of closing the life cycles of bio-resources.

\subsection{Contextual rules for sustainably balancing bio-resource utilisation}

Bio-resources are contextual resources. The generation of primary resources is dependent on a concrete ecosystem. Demand for resources as well as the generation of secondary resources is shaped by socio-economic context. The decision how to sustainably balance the use of bioresources is therefore only possible if the context is taken into account. This means that rules that guide such decisions have to be context related.

\subsubsection{Developing a sustainable bio-resource utilisation system}

Besides preserving or even improving ecological performance of land and providing nutrition, bio-resources are the fundament for creation of sustainable jobs and wealth in rural regions. These are services that may not be provided by other resources and must therefore be given priority (within the framework established by the fulfilment of ecological services and the provision of food) before fulfilling other requests to bio-resources.

There is no general rule for providing these services. The pathway towards achieving the goal of sustainable regional development is dependent on a range of contextual parameters such as the existing economic structure (e.g. the existence of conventional sectors of bio-resource utilisation), the existence of markets for particular products and services as well as education and qualification levels in the region, to name the most prominent. Sustainable development requires that the utilisation of bio-resources becomes a major factor for spatial planning which in turn must take over a strong co-ordinating role balancing resource provision and consumption in the spatial context (Stoeglehner et al., 2011). 


\subsubsection{Heuristics for optimal regional bio-resource utilisation}

The following notions can be seen as heuristics guiding a regional discourse about utilising bio-resources based on the properties, technological aspects and service provision priorities presented earlier in this article.

\section{"Refinerize" conventional sectors}

Bio-resources are the only possible basis for sectors that conventionally utilise wood and crops such as pulp \& paper, timber or oils and fats industry but also the food sector. These sectors provide products that cannot easily be replaced by other goods or services and render decent profits along their value chain. Moreover such industries have established well organised logistical systems and provide jobs and income as well as skills and qualification for employees. Putting priority to serving these sectors is sensible and in the case of the food sector even obligatory.

The sectors themselves, however, have to evolve into flexible bio-refinery systems based on their main resource but accommodating other (secondary) bio-resources provided by their spatial and economic context. This strategy serves two objectives:

- Employing existing logistic systems as well as skills and technological infrastructure to realising the rule of fully utilising sustainably available bio-resources and

- Offering a broader portfolio of goods and services from available bio-resources thus adding to the necessary flexibility of markets, accommodating possible shifts in preferences of consumers in a sustainable bio-based economy.

This means that the function of conventional sector industrial sites in a bio-based economy will more and more resemble that of oil refineries in a fossil economy: transforming main resources into diverse products for many different markets, adding economic stability to the advantage of economy of scale following the rules of industrial ecology with different processes co-operating symbiotically to achieve maximum resource efficiency.

\section{Give priority to material goods}

Material goods provide higher added value on the resource than energy services as they offer opportunities for longer and more complex value chains. Their provision therefore will bolster the economic viability of a bio-economy. The range of such products however is wide, from simple solid biomass fuel such as wood pellets to gaseous and liquid biofuels to bio-plastics to complex pharmaceutical products.

As a rule of the thumb value added to resources increases with more complex and longer value chains as well as with more complex products. The higher the complexity of products, the more specialised, centralised and larger production units will become. The more valuable (and usually more complex) products are, the lower is the economic impact of raw material costs and the higher will be the requirements for raw material quality, as higher input quality reduces complexity and cost of downstream processes separating, cleaning and polishing end-products. 


\section{Retain as much material as possible close to productive land}

Preserving the productivity of the primary resource land is to a large extent depending on closing material cycles and returning nutrients to the land. This requires that any part of bio-resources that is not converted into material goods (be they nutritional or for other purposes) shall be recycled to fields, grass land and forests where they have been taken from. As most of the waste flows generated by the utilisation of bio-resources have particularly unfavourable logistic parameters their transport distances must be kept short. This demands that technologies conditioning bio-resources for further use or transport (which are front line technologies in the life cycle of bio-resources) as well as technologies conditioning bio-waste (which constitute the rear guard of the life cycle) shall preferably be realized de-centrally, close to the origin of bio-resources.

\section{Use intersections of distribution grids as a means to fully utilise bio-resources}

Rear guard technologies like combustion and bio-gas have a narrow product portfolio: combustion provides heat, heat and power (in case of CHP) and biogas can be up-graded to biomethane or used in a CHP to generate heat and power. All these products may be distributed via distribution grids. The optimum location for these technologies therefore is where these grids intersect (Stoeglehner \& Narodoslawsky, 2012).

Particularly advantageous are trivalent technologies. These are technologies that produce biomethane either from anaerobic digestion in combination with gas cleaning or from biomass gasification with catalytic conversion to synthetic natural gas. These technologies can serve all energy distribution grids, from heat to electricity to gas. These technologies should be operated according to the electricity grid requirements, switching to gas production whenever no electricity is necessary to stabilise the grid and serve heat customers via heat storage systems.

The necessary proximity of heat users to thermal bio-energy providers gives raise to another type of bio-refinery: de-central bio-refineries converting secondary or under-utilised bio-resources to intermediate "platform" materials, improving quality and transport properties and conditioning these bio-resources for processing in central large scale bio-refineries. This approach pursues three objectives in conformity with the rules defined above:

- Technologies transforming bio-resources to platform products more often than not require large amounts of heat (for drying as well as process heat). This provides stable demand for heat as the low-end service of de-central bio-based energy systems thus utilising bio-resources fully.

- Many of these technologies separate large parts of the bio-resources that will not enter industrial life cycles (removing bark from timber, removing the press cake from silage in Green Bio-Refineries or oil presses, etc.) which may be utilised in the de-central energy systems themselves or returned to agriculture (as feedstock, e.g. press cakes) or fertilizer (e.g. ashes). This conforms to the rule to retain as much material as possible close to the land from which bio-resources are taken.

- These bio-refineries add considerable value to the bio-resources directly at the region of their emergence, thus providing jobs and social stability. 


\section{Conclusion}

The arguments presented in this paper are based on the assumption that future global development will be oriented according to the concept of strong sustainability. This particular development pathway is however only one of possible ways human society may structure its future. Sustainable development in itself is not a logical continuation of our current economic system and requires without doubt political will and profound societal change on a global scale for its implementation.

The further human society however moves towards sustainable development, the more important a bio-based economy using renewable resources will become. This calls for rational management of these most valuable of renewable resources and in particular for efficient use of these resources. Current levels of waste in food provision must therefore be brought down substantially in the face of growing human population and the many services that bio-resources will have to fulfil in a sustainable bio-based economy.

The approach offered in this paper proposes to balance the use of bio-resources according to the services they may provide in a sustainable economy. Services that can only be provided by bio-resources shall be given priority. This applies in particular to nutrition, but also to the environmental services that the provision of bio-resources has to fulfil. It is within the framework of the obligations to these services that all other services may be provided by bio-resources.

Transport matters much more for bio-resources than for fossil resources that compete with them in many industrial applications. Moreover quality and quantity of bio-resources are dependent on the natural endowment in a region. This means that decisions about utilisation of bio-resources must always be taken within a concrete regional context, based on a societal discourse that defines responsibilities for nutrition and sustainable management of environment, but also chances and objectives of the utilisation of bio-resources. Given the complex technological possibilities and logistical considerations this discourse often requires the help of planning instruments (Kettl et al., 2011, RegiOpt software available from www.fussabdrucksrechner.at [accessed June 2014]).

Bio-resource utilisation will become a pivotal technological as well as economic and societal challenge in the transformation towards a sustainable economy. Although they are renewable and therefore available infinitely, they are limited by the finite availability of the basic resource of fertile land necessary to generate them. Given the competition for land to support food production, major focus for the provision of all other services from bio-resources will have to be laid on secondary or under-utilised bio-resources. This will require major technological as well as economic break-through for fully utilising these valuable resources in future. 


\section{References}

Beer, C., Reichstein, M., Tomelleri, E., Ciais, P., Jung, M., Carvalhais, N., Rödenbeck, C., Arain, M.A., Baldocchi, D., Bonan, G.B., Bondeau, A., Cescatti, A., Lasslop, G., Lindroth, A., Lomas, M., Luyssaert, S., Margolis, H., Oleson, K.W., Roupsard, O., Veenendaal, E., Viovy, N., Williams, C., Woodward, F.I. and Papale, D., 2010: Terrestrial Gross Carbon Dioxide Uptake: Global Distribution and Covariation with Climate. Science, 329 (5993), 834-838

Deutsche Bank, 2012: State-of-the-art electricity storage systems, accessible from http://www.dbresearch.com/PROD/DBR_INTERNET_EN-PROD/PROD00000000000286166/Stateof-the\%20art+electricity+storage+systems\%3A+Indispensable+elements+of+the+energy+ r\%20evolution.pdf, [accessed November 2014]

EC (European Commission), 2007 a: Limiting Global Climate Change to 2 degrees Celsius - The way ahead for 2020 and beyond, COM(2007) 2 final, EC, Brussels

EC (European Commission), 2007 b: A European Strategic Energy Technology Plan (SET-PLAN) - Towards a Low Carbon Future, COM(2007) 723 final, EC, Brussels

FAO (Food and Agriculture Organization of the United Nations), 2006: Livestock's long shadow - environmental issues and options, accessible from:

ftp://ftp.fao.org/docrep/fao/010/a0701e/a0701e.pdf, [accessed November 2014]

Favennec, J.-P., 2011: The Geopolitics of Energy, Editions Technip, Paris

Gosh, B.B., Banerjee, A.K., 1984: Production of single cell protein from hydrocarbons by arthrobacter simplex 162. Folio Microbiol., 29, 222-226

Gwehenberger, G., Narodoslawsky, M., Liebmann, B., Friedl, A., 2007: Ecology of Scale versus Economy of Scale for Bioethanol Production. Biofuels, Bioprod. Bioref. 1 (4), 264-269

Gwehenberger, G., Narodoslawsky, M., 2008. Sustainable processes - The challenge of the $21^{\text {st }}$ century for chemical engineering, Process Safety and Environmental Protection, 86 (5), 321-327

Gustavsson, J., Cederberg, Ch., Sonesson, U., van Otterdijk R., Meybeck, A, 2011: Global food losses and food waste, FAO, Rome, accessible via http://www.fao.org/docrep/014/mb060e/mb060e00.pdf, [accessed November 2014]

Haberl, H., Erb, K.-H., Krausmann, F., Gaube, V., Bondeau, A., Plutzar, Ch., Gingrich, S., Lucht, W., Fischer-Kowalski, M., 2007: Quantifying and mapping the human appropriation of net primary production in earth's terrestrial ecosystems, Proc. Natl. Acad. Sci. USA, 104 (31), 12942-12947

IEA-ETSAP \& IRENA, 2013: Thermal Energy Storage - Technology Brief, accessible via http://www.irena.org/DocumentDownloads/Publications/IRENA-ETSAP\%20Tech\%20Brief \%20E17\%20Thermal\%20Energy\%20Storage.pdf, [accessed November 2014]

Kettl, K.-H., Niemetz, N., Sandor, N.K., Eder, M., Narodoslawsky, M., 2011: Ecological Impact of Renewable Resource-Based Energy Technologies. Journal of fundamentals of renewable energy and applications, 1, doi:10.4303/frea/R101101

Kettl, K.-H., Niemetz, N., Sandor, N. K., Eder, M., Heckl, I., Narodoslawsky, M., 2011: Regional Optimizer (RegiOpt) - Sustainable energy technology network solutions for regions, Computer Aided Chemical Engineering, DOI:10.1016/B978-0-444-54298-4.50170-7 
Stoeglehner, G., Niemetz, N., Kettl, K.-H., 2011: Spatial dimensions of sustainable energy systems: new visions for integrated spatial and energy planning. Energy, Sustainability and Society, 1, 1-9

Stoeglehner, G., Narodoslawsky, M., 2012: Integrated optimization of spatial structures and energy systems. In: Stremke, S., Van den Dobbelsteen, A., Sustainable Energy Landscapes: Designing, Planning and Development. Taylor \& Francis, Boca Raton

Yergin, D., 2011: The Quest: Energy, Security, and the Remaking of the Modern World. Penguin Press, New York

Zhu, X.-G., Long, St.P., Ort, D.R., 2008: What is the maximum efficiency with which photosynthesis can convert solar energy into biomass? Current Opinion in Biotechnology, 19, 153-159 


\section{Previously published manu:scripts}

ITA-01-01 Gunther Tichy, Walter Peissl (12/2001): Beeinträchtigung der Privatsphäre in der Informationsgesellschaft.

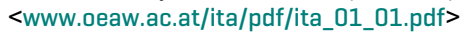

ITA-01-02 Georg Aichholzer (12/2001): Delphi Austria: An Example of Tailoring Foresight to the Needs of a Small Country. <www.oeaw.ac.at/ita/pdf/ita_01_02.pdf>

ITA-01-03 Helge Torgersen, Jürgen Hampel (12/2001): The Gate-Resonance Model: The Interface of Policy, Media and the Public in Technology Conflicts. <www.oeaw.ac.at/ita/pdf/ita_01_03.pdf>

ITA-02-01 Georg Aichholzer (1/2002): Das ExpertInnen-Delphi: Methodische Grundlagen und Anwendungsfeld "Technology Foresight". <www.oeaw.ac.at/ita/pdf/ita_02_01.pdf>

ITA-02-02 Walter Peissl (1/2002): Surveillance and Security - A Dodgy Relationship. $<$ www.oeaw.ac.at/ita/pdf/ita_02_02.pdf>

ITA-02-03 Gunther Tichy (2/2002): Informationsgesellschaft und flexiblere Arbeitsmärkte. <www.oeaw.ac.at/ita/pdf/ita_02_03.pdf>

ITA-02-04 Andreas Diekmann (6/2002): Diagnose von Fehlerquellen und methodische Qualität in der sozialwissenschaftlichen Forschung. <www.oeaw.ac.at/ita/pdf/ita_02_04.pdf>

ITA-02-05 Gunther Tichy (10/2002): Over-optimism Among Experts in Assessment and Foresight. $<w w w . o e a w . a c . a t /$ ita/pdf/ita_02_05.pdf>

ITA-02-06 Hilmar Westholm (12/2002): Mit eDemocracy zu deliberativer Politik? Zur Praxis und Anschlussfähigkeit eines neuen Mediums. <www.oeaw.ac.at/ita/pdf/ita_02_06.pdf>

ITA-03-01 Jörg Flecker und Sabine Kirschenhofer (01/2003): IT verleiht Flügel? Aktuelle Tendenzen der räumlichen Verlagerung von Arbeit. <www.oeaw.ac.at/ita/pdf/ita_03_01.pdf>

ITA-03-02 Gunther Tichy (11/2003): Die Risikogesellschaft - Ein vernachlässigtes Konzept in der europäischen Stagnationsdiskussion. <www.oeaw.ac.at/ita/pdf/ita_03_02.pdf>

ITA-03-03 Michael Nentwich (11/2003): Neue Kommunikationstechnologien und Wissenschaft - Veränderungspotentiale und Handlungsoptionen auf dem Weg zur Cyber-Wissenschaft. <www.oeaw.ac.at/ita/pdf/ita_03_03.pdf>

ITA-04-01 Gerd Schienstock (1/2004): Finnland auf dem Weg zur Wissensökonomie - Von Pfadabhängigkeit zu Pfadentwicklung. <www.oeaw.ac.at/ita/pdf/ita_04_01.pdf>

ITA-04-02 Gunther Tichy (6/2004): Technikfolgen-Abschätzung: Entscheidungshilfe in einer komplexen Welt. <www.oeaw.ac.at/ita/pdf/ita_04_02.pdf>

ITA-04-03 Johannes M. Bauer (11/2004): Governing the Networks of the Information Society - Prospects and limits of policy in a complex technical system. <www.oeaw.ac.at/ita/pdf/ita_04_03.pdf>

ITA-04-04 Ronald Leenes (12/2004): Local e-Government in the Netherlands: From Ambitious Policy Goals to Harsh Reality. <www.oeaw.ac.at/ita/pdf/ita_04_04.pdf>

ITA-05-01 Andreas Krisch (1/2005): Die Veröffentlichung des Privaten - Mit intelligenten Etiketten vom grundsätzlichen Schutz der Privatsphäre zum Selbstschutz-Prinzip. <www.oeaw.ac.at/ita/pdf/ita_05_01.pdf>

ITA-05-02 Petra Grabner (12/2005): Ein Subsidiaritätstest - Die Errichtung gentechnikfreier Regionen in Österreich zwischen Anspruch und Wirklichkeit. <http://epub.oeaw.ac.at/ita/ita-manuscript/ita_05_02.pdf>

ITA-05-03 Eva Buchinger (12/2005): Innovationspolitik aus systemtheoretischer Sicht - Ein zyklisches Modell der politischen Steuerung technologischer Innovation. <www.oeaw.ac.at/ita/pdf/ita_05_03.pdf>

ITA-06-01 Michael Latzer (6/2006): Medien- und Telekommunikationspolitik: Unordnung durch Konvergenz - Ordnung durch Mediamatikpolitik. <epub.oeaw.ac.at/ita/ita-manuscript/ita_06_01.pdf>

ITA-06-02 Natascha Just, Michael Latzer, Florian Saurwein (9/2006): Communications Governance: Entscheidungshilfe für die Wahl des Regulierungsarrangements am Beispiel Spam. <epub.oeaw.ac.at/ita/ita-manuscript/ita_06_02.pdf>

ITA-06-03 Veronika Gaube, Helmut Haberl (10/2006): Sozial-ökologische Konzepte, Modelle und Indikatoren nachhaltiger Entwicklung: Trends im Ressourcenverbrauch in Österreich. <epub.oeaw.ac.at/ita/ita-manuscript/ita_06_03.pdf>

ITA-06-04 Maximilian Fochler, Annina Müller (11/2006): Vom Defizit zum Dialog? Zum Verhältnis von Wissenschaft und Öffentlichkeit in der europäischen und österreichischen Forschungspolitik. <epub.oeaw.ac.at/ita/ita-manuscript/ita_06_04.pdf>

ITA-06-05 Holger Floeting (11/2006): Sicherheitstechnologien und neue urbane Sicherheitsregimes <epub.oeaw.ac.at/ita/ita-manuscript/ita_06_05.pdf>

ITA-06-06 Armin Spök (12/2006): From Farming to „Pharming” - Risks and Policy Challenges of Third Generation GM Crops. <epub.oeaw.ac.at/ita/ita-manuscript/ita_06_06.pdf>

ITA-07-01 Volker Stelzer, Christine Rösch, Konrad Raab (3/2007): Ein integratives Konzept zur Messung von Nachhaltigkeit - das Beispiel Energiegewinnung aus Grünland. <epub.oeaw.ac.at/ita/ita-manuscript/ita_07_01.pdf>

ITA-07-02 Elisabeth Katzlinger (3/2007): Big Brother beim Lernen: Privatsphäre und Datenschutz in Lernplattformen. <epub.oeaw.ac.at/ita/ita-manuscript/ita_07_02.pdf>

ITA-07-03 Astrid Engel, Martina Erlemann (4/2007): Kartierte Risikokonflikte als Instrument reflexiver Wissenspolitik <epub.oeaw.ac.at/ita/ita-manuscript/ita_07_03.pdf>

ITA-07-04 Peter Parycek (5/2007): Gläserne Bürger - transparenter Staat? Risiken und Reformpotenziale des öffentlichen Sektors in der Wissensgesellschaft. <epub.oeaw.ac.at/ita/ita-manuscript/ita_07_04.pdf>

ITA-07-05 Helge Torgersen (7/2007): Sicherheitsansprüche an neue Technologien - das Beispiel Nanotechnologie. <epub.oeaw.ac.at/ita/ita-manuscript/ita_07_05.pdf>

ITA-07-06 Karen Kastenhofer (9/2007): Zwischen „schwacher“ und „starker“ Interdisziplinarität. Die Notwendigkeit der Balance epistemischer Kulturen in der Sicherheitsforschung zu neuen Technologien. <epub.oeaw.ac.at/ita/ita-manuscript/ita_07_06.pdf> 
ITA-07-07 Ralf Lindner, Michael Friedewald (9/2007): Gesellschaftliche Herausforderungen durch „intelligente Umgebungen. Dunkle Szenarien als TA-Werkzeug. <epub.oeaw.ac.at/ita/ita-manuscript/ita_07_07.pdf>

ITA-07-08 Alfons Bora (11/2007): Die disziplinären Grundlagen der Wissenschaft. <epub.oeaw.ac.at/ita/ita-manuscript/ita_07_08.pdf>

ITA-08-01 Alexander Degelsegger (5/2008): „Frames“ in sozialwissenschaftlichen Theorieansätzen. Ein Vergleich aus der Perspektive der Technikforschung. <epub.oeaw.ac.at/ita/ita-manuscript/ita_08_01.pdf>

ITA-08-02 Jens Hoff (11/2008): Can The Internet Swing The Vote? Results from a study of the 2007 Danish parliamentary election. <epub.oeaw.ac.at/ita/ita-manuscript/ita_08_02.pdf>

ITA-09-01 Georg Aichholzer, Doris Allhutter (2/2009): e-Participation in Austria: Trends and Public Policies. <epub.oeaw.ac.at/ita/ita-manuscript/ita_09_01.pdf>

ITA-09-02 Michael Nentwich (11/2009): Cyberscience 2.0 oder 1.2? Das Web 2.0 und die Wissenschaft. <epub.oeaw.ac.at/ita/ita-manuscript/ita_09_02.pdf>

ITA-09-03 Hilmar Westholm (12/2009): Wandel der Formen politischer Partizipation und der Beitrag des Internet. Schlussfolgerungen aus Bevölkerungsbefragungen in Deutschland. <epub.oeaw.ac.at/ita/ita-manuscript/ita_09_03.pdf>

ITA-10-01 Iris Eisenberger (12/2010): Kleine Teile, große Wirkung? Nanotechnologieregulierung in der Europäischen Union. <epub.oeaw.ac.at/ita/ita-manuscript/ita_10_01.pdf>

ITA-10-02 Alexander Degelsegger and Helge Torgersen (12/2010): Instructions for being unhappy with PTA. The impact on PTA of Austrian technology policy experts' conceptualisation of the public. <epub.oeaw.ac.at/ita/ita-manuscript/ita_10_02.pdf>

ITA-10-03 Ernest Braun (12/2010): The Changing Role of Technology in Society. <epub.oeaw.ac.at/ita/ita-manuscript/ita_10_03.pdf>

ITA-10-04 Fritz Betz (12/2010): E-Partizipation und die Grenzen der Diskursethik. <epub.oeaw.ac.at/ita/ita-manuscript/ita_10_04.pdf>

ITA-11-01 Peter Parycek, Judith Schoßböck (1/2011): Transparency for Common Good. Offener Zugang zu Information im Kontext gesellschaftlicher und strategischer Spannungsfelder. <epub.oeaw.ac.at/ita/ita-manuscript/ita_11_01.pdf>

ITA-11-02 Georg Aichholzer und Doris Allhutter (6/2011): Online forms of political participation and their impact on democracy. <epub.oeaw.ac.at/ita/ita-manuscript/ita_11_02.pdf>

ITA-11-03 Mahshid Sotoudeh, Walter PeissI, Niklas Gudowsky, Anders Jacobi (12/2011): Long-term planning for sustainable development. CIVISTI method for futures studies with strong participative elements. <epub.oeaw.ac.at/ita/ita-manuscript/ita_11_03.pdf>

ITA-12-01 Xiao Ming (1/2012): e-Participation in Government Decision-Making in China. Reflections on the Experience of Guangdong Province. <epub.oeaw.ac.at/ita/ita-manuscript/ita_12_01.pdf>

ITA-12-02 Stephan Bröchler, Georg Aichholzer, Petra Schaper-Rinkel (Hrsg.) (9/2012): Theorie und Praxis von Technology Governance. <epub.oeaw.ac.at/ita/ita-manuscript/ita_12_02_Sondernummer.pdf>

ITA-12-03 Iris Eisenberger (10/2012): EU-Verhaltenskodex Nanotechnologie: Rechtsstaatliche und demokratische Aspekte. <epub.oeaw.ac.at/ita/ita-manuscript/ita_12_03.pdf>

ITA-12-04 Julia Haslinger, Christiane Hauser, Peter Hocke, Ulrich Fiedeler (10/2012): Ein Teilerfolg der Nanowissenschaften? Eine Inhaltsanalyse zur Nanoberichterstattung in repräsentativen Medien Österreichs, Deutschlands und der Schweiz. <epub.oeaw.ac.at/ita/ita-manuscript/ita_12_04.pdf>

ITA-13-01 Helge Torgersen, Alexander Bogner, Karen Kastenhofer (10/2013): The Power of Framing in Technology Governance: The Case of Biotechnologies. <http://epub.oeaw.ac.at/ita/ita-manuscript/ita_13_01.pdf>

ITA-13-02 Astrid Mager (11/2013): In search of ideology. Socio-cultural dimensions of Google and alternative search engines. <epub.oeaw.ac.at/ita/ita-manuscript/ita_13_02.pdf>

ITA-13-03 Petra Wächter (12/2013): Aspekte einer nachhaltigen Energiezukunft. <epub.oeaw.ac.at/ita/ita-manuscript/ita_13_03.pdf>

ITA-14-01 Renate Mayntz (8/2014): Technikfolgenabschätzung - Herausforderungen und Grenzen. <epub.oeaw.ac.at/ita/ita-manuscript/ita_14_01.pdf>

ITA-14-02 Michael Narodoslawsky (11/2014): Utilising Bio-resources: Rational Strategies for a Sustainable Bio-economy. <epub.oeaw.ac.at/ita/ita-manuscript/ita_14_02.pdf> 